\title{
IMPORTANCE OF ENDOTHORACIC LYMPH NODES IN PULMONARY DISEASE IN CHILDHOOD AND ADOLESCENCE*
}

\author{
BY \\ I. SZÖTS and F. DÁNIEL \\ From the Second Surgical Clinic of the Budapest University
}

Recently greater attention has been given to the pathological changes of the bronchi and parenchyma caused by tuberculosis of the endothoracic lymph nodes. There is general agreement that though many cases show no symptoms, inevitable lesions sometimes follow. According to the data of Görgényi-Göttche (1958), $15-20 \%$ of patients in Hungarian institutes for tuberculous children have so-called 'epituberculous' lesions.

The combined antituberculous therapy employed today cannot prevent perforation of the lymph nodes, and because of the development of bronchial stenosis and its consequences (developed in spite of careful bronchoscopic treatment), a great many patients come to operation.

We have reviewed the case histories of tuberculous endotracheal lymph nodes in our clinic over a 10-year period. Between 1951 and 1960 we carried out 303 lung resections in 296 children and adolescents. Their distribution according to diagnosis is shown in Table 1.

The distribution according to age and sex is contained in Table 2 (our youngest patient was 2 months old).

In $70.7 \%$ of the 146 resections for tuberculosis, in $36.2 \%$ of the 98 resections for bronchiectasis

* A paper read at a meeting of British Association of Paediatric Surgeons in Stockholm, September 1961. and in more than half the cases of chronic suppurative lung diseases, we found the bronchial system

TABLE 1

DISTRIBUTION OF RESECTIONS ACCORDING TO DIAGNOSIS

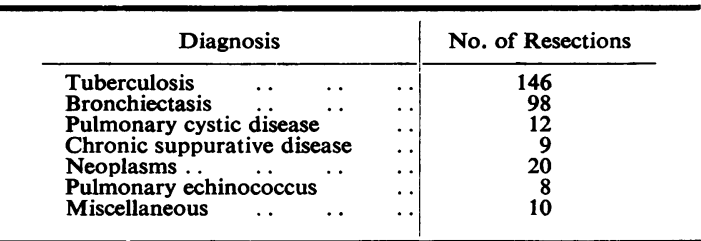

damaged by tuberculosis of the lymph nodes. This is demonstrated by the diagram (Fig. 1).

The first column indicates the number of tuberculous resections; its shadowed part shows the 103 cases in which the lymph nodes played some role.

The indications for resections carried out on tuberculosis can be summarized as follows:

(a) In three cases segmental resection was carried out for primary tuberculosis. All three patients had persistently positive pulmonary secretions, in spite of antituberculous treatment for three years, and one of them had repeated haemoptysis.

(b) Resections were carried out for tumour-like enlarged bronchial nodes or for those which were likely to perforate. They compressed the bronchus

TABLE 2

AGE AND SEX DISTRIBUTION IN 296 PATIENTS UNDERGOING RESECTION FOR PULMONARY DISEASES

\begin{tabular}{|c|c|c|c|c|c|c|}
\hline \multirow{2}{*}{$\underset{\text { (years) }}{\text { Age }}$} & \multicolumn{2}{|c|}{ Total } & \multicolumn{2}{|c|}{ Boys } & \multicolumn{2}{|c|}{ Girls } \\
\hline & Specific & Non-specific & Specific & Non-specific & Specific & Non-specific \\
\hline $\begin{array}{c}0-5 \\
6-10 \\
11-14 \\
14-18\end{array}$ & $\begin{array}{r}-5 \\
59 \\
82\end{array}$ & $\begin{array}{l}25 \\
52 \\
41 \\
39\end{array}$ & $\begin{array}{r}-2 \\
23 \\
35\end{array}$ & $\begin{array}{l}13 \\
30 \\
20 \\
17\end{array}$ & $\begin{array}{r}-3 \\
36 \\
47\end{array}$ & $\begin{array}{l}12 \\
22 \\
21 \\
22\end{array}$ \\
\hline Total & 146 & 157 & 60 & 80 & 86 & 77 \\
\hline
\end{tabular}




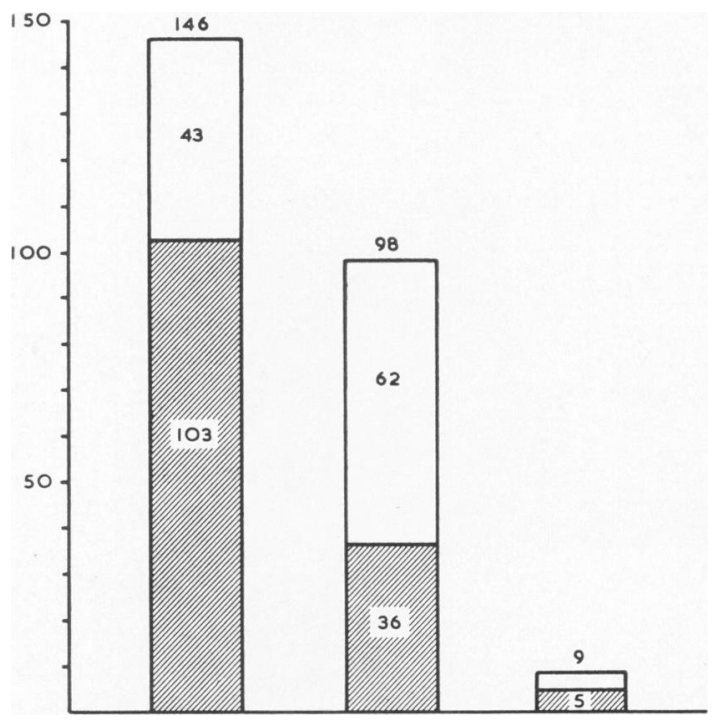

FIG. 1.-The first column shows resections for tuberculosis; the second column indicates the number of resections for bronchiectasis, and the third the number of resections for chronic suppurative lung disease. The shaded areas show the number of cases in which the lymph nodes played a part.

and did not react to conservative treatment. We removed the lymph node separately or, if the bronchus was damaged, the operation was combined with a segmental resection. Plastic operation of the bronchus, excision of the involved bronchus and bronchial anastomosis can be taken into consideration as well.

(c) The majority of the patients (nearly $70 \%$ ) were in hospital for the late complications of primary tuberculosis.

(d) Excision was carried out for specific endobronchitis in 20 cases.

(e) A relatively smaller proportion of the lung operations consisted of resections for tuberculosis of adult type ( 23 cases, i.e. $15 \cdot 6 \%$ ).

The distribution of resections according to extent is given in Table 3.

There was one death due to postoperative bleeding among the 146 resections for tuberculosis $(0 \cdot 68 \%)$.

In the follow-up period of one to nine years we observed only three relapses $(2 \cdot 76 \%)$. Among the 157 lung resections for non-specific diseases, there were two early deaths within three months $(1 \cdot 27 \%)$, one due to postoperative shock, the other due to suffocation (wet lung). Their distribution according to extent is shown in Table 4.

The most commonly observed bronchial perforation was found on the intermedial bronchus and on the right side.
TABLE 3

EXTENT OF PULMONARY RESECTIONS FOR TUBERCULOSIS

\begin{tabular}{|c|c|}
\hline Extent & No. of Resections \\
\hline $\begin{array}{lccc}\begin{array}{l}\text { Pulmonectomy } \\
\text { Bilobectomy }\end{array} & \ldots & \ldots & \ldots \\
\text { Lobectomy and segmental resection } \\
\begin{array}{l}\text { Lobectomy } . . \\
\text { Segmental resection }\end{array} \\
\begin{array}{l}\text { Wedge resection } \\
\text { extirpation }\end{array} \text {.. } & \ldots & \ldots & \ldots \\
\text { lymph } & \text { node }\end{array}$ & $\begin{array}{r}23 \\
6 \\
14 \\
54 \\
42 \\
7\end{array}$ \\
\hline Total .. & 146 \\
\hline
\end{tabular}

TABLE 4

EXTENT OF PULMONARY RESECTION FOR NON-SPECIFIC RESPIRATORY DISEASE

\begin{tabular}{|c|c|c|}
\hline \multicolumn{2}{|c|}{ Extent } & No. of Resections \\
\hline $\begin{array}{l}\text { Pulmonectomy } \\
\text { Bilobectomy . . } \\
\text { Lobectomy and segm } \\
\text { Lobectomy . . } \\
\text { Segmental resection } \\
\text { Extirpation ... }\end{array}$ & $\begin{array}{ccc} & \ldots & \cdots \\
\cdots & \ldots & \cdots \\
\text { nental resection } \\
\ldots & \ldots & \cdots \\
\ldots & \ldots & \cdots \\
\cdots & \ldots & \cdots\end{array}$ & $\begin{array}{r}30 \\
15 \\
27 \\
48 \\
7 \\
30\end{array}$ \\
\hline Total & $\ldots$ & 157 \\
\hline
\end{tabular}

\section{Case Report}

A 16-year-old girl, who had never been ill before, came to our clinic in January 1958. She had an atelectasis in the right eighth segment, from which an abscess developed in a month. Tuberculin test was positive, bronchus secretion negative. She received antibiotic and chemotherapeutic treatment for six months, but the cavity remained unchanged.

Bronchoscopy. On the medial wall of the right eighth segmental bronchus was an impression, covered by a greyish-white secretion. The lymph node appeared to be about to perforate.

Bronchography. The middle lobe bronchus was stenotic round its origin, the eighth and ninth bronchial segments are filled only for a short distance, and their visible parts are markedly widened (Figs. 2 and 3).

Operative Findings. After isolating the middle lobe bronchus, a nut-sized caseous lymph node was found which had perforated into the bronchus intermedius, producing an opening of $0.5 \mathrm{~cm}$. (Fig. 4). The lumen of the middle lobe bronchus at its beginning was deformed and stenosed by a residium of lymph node which was caseous in the centre and scarred peripherally. In the lower lobe bronchus there was an opening of $5 \mathrm{~mm}$. The bronchus of the eighth segment was deformed and stenosed by a tuberculous lymph node, the centre of which had caseated and had penetrated into the lumen of the eighth segment bronchus (Figs. 5 and 6).

Comment. So we have here a threefold perforation of a bronchus: a recent penetration into the bronchus intermedius with current active tuberculous changes, 


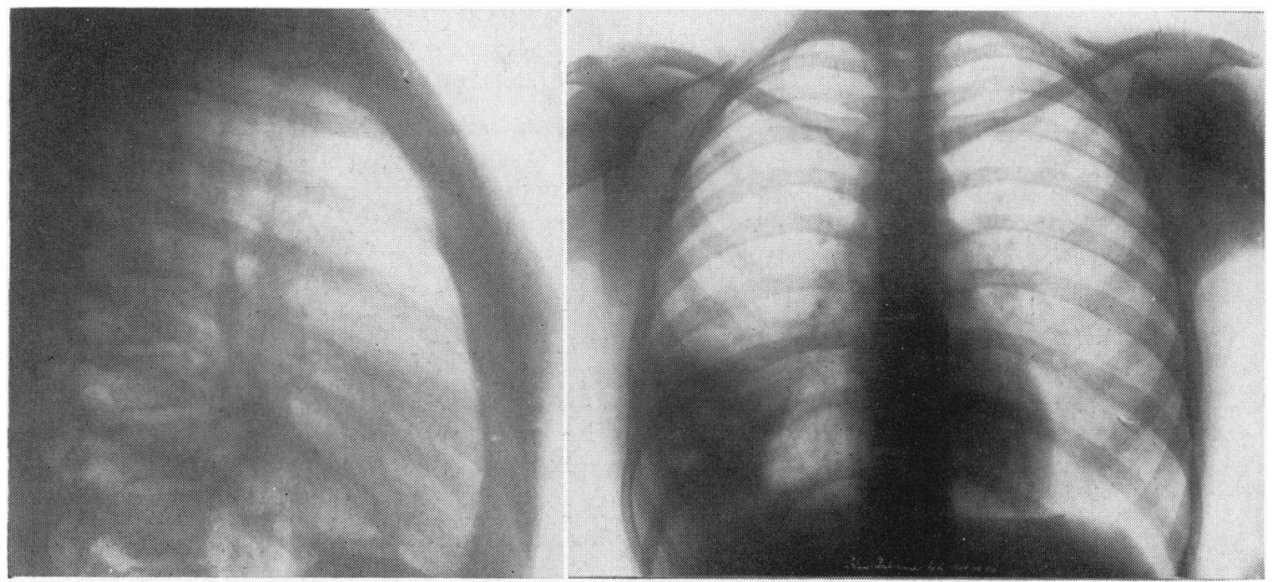

FIG. 2.-Postero-anterior and lateral radiographs of the chest, showing an abscess cavity with a fluid level and surrounding pneumonitis.

a penetration into the middle lobe bronchus and a third one into the eighth segmental bronchus. There is pyosclerosis in the eighth segment, and there are specific nodulous foci in the seventh segment.

\section{Discussion}

The problem of the time of operation in relation to bronchial alteration has not as yet been solved. The perforation of lymph nodes cannot be prevented by drug treatment. If they cause an irreversible change of the bronchial system, operation may become necessary. The question of the removal of the pathologically enlarged lymph node must be decided individually in every case. The surgical treatment of irreversible lymph node changes is always indicated in childhood, as children tolerate thoracic operations better than adults and the operation risk is less.

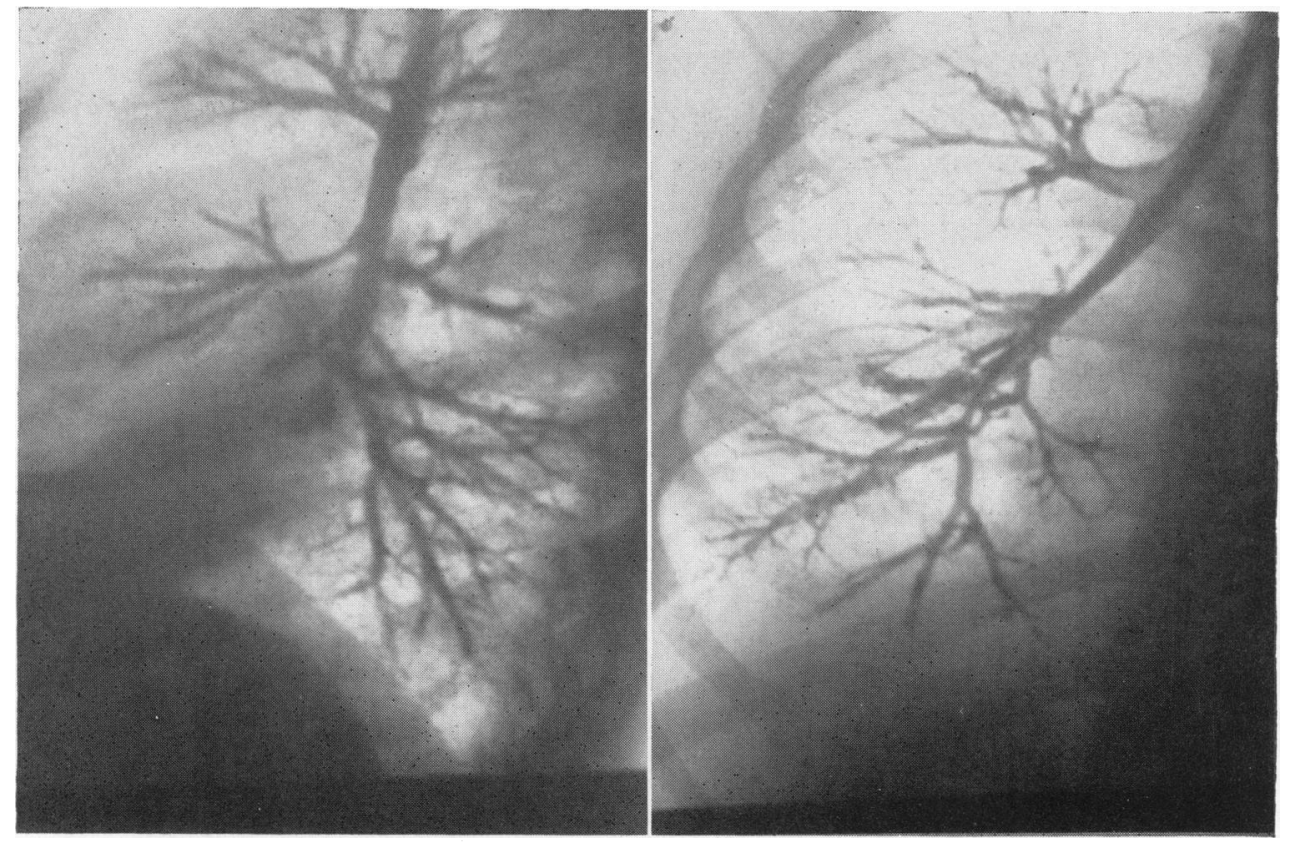

FIC. 3 


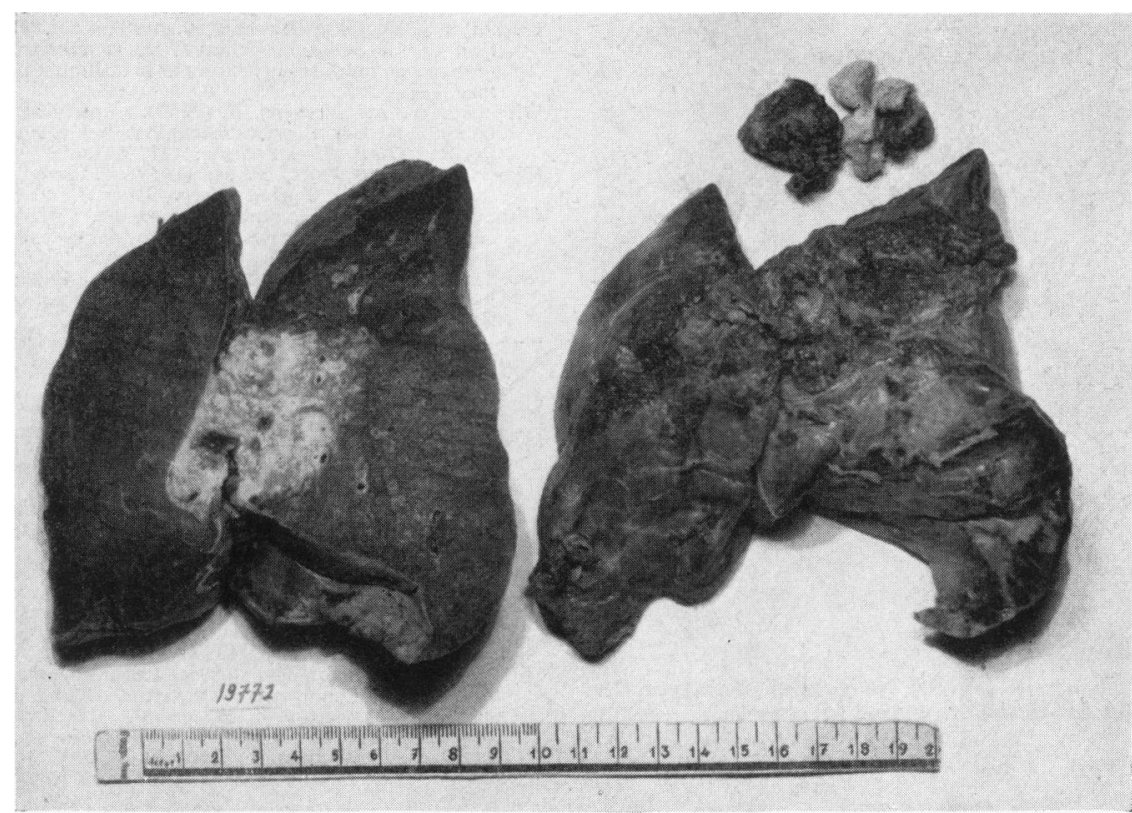

Fig. 4.-The removed specimen: middle and lower lobe, lymph nodes in the upper part.

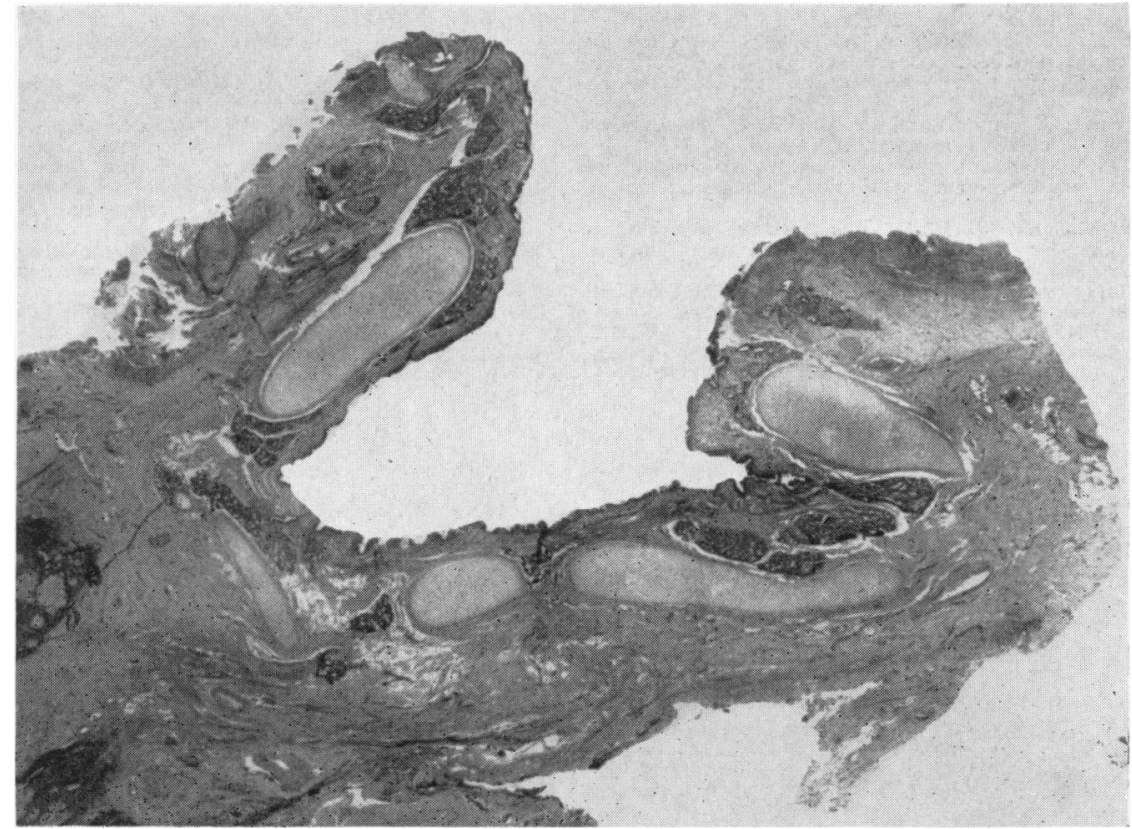

FIG. 5.-Photomicrograph of the perforation of the bronchus. At the top is the wide opening of the perforation. 


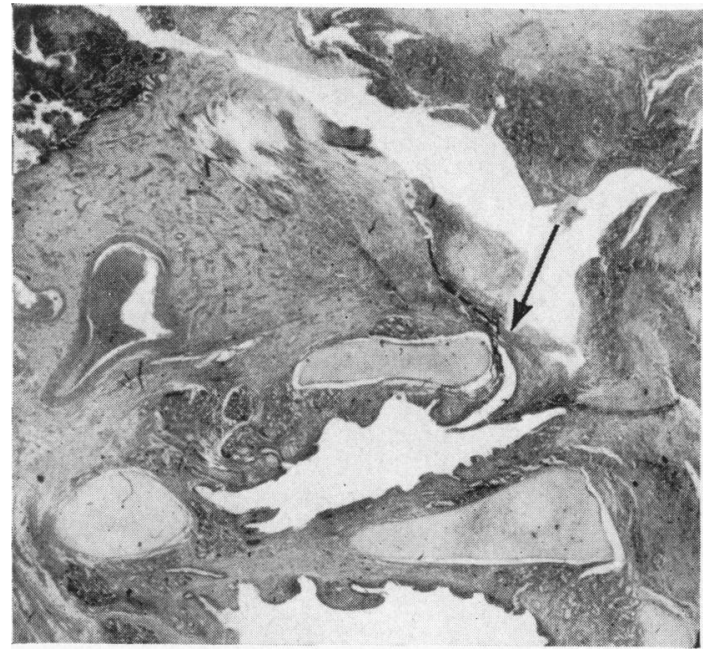

FIG. 6.-Photomicrograph of the compressed bronchus. The perforation opening is marked by an arrow.

\section{BIBLIOGRAPHY}

Boyd, G. L. (1957). Solid intrathoracic masses in children. Pediatrics, 19, 142.

Brügger, H. (1959). Die Bedeutung des Lymphknotens im Ablauf der Primärtuberkulose. Z. Tuberk., 114, 15

Cameron, J. K., Hay, J. D. and Temple, L. J. (1957). A critical examination of the role of surgery in the treatment of primary pulmonary tuberculosis in children. Thorax, 21, 329.

Chesterman, J. T. (1957). The surgery of primary pulmonary tuberculosis in children. ibid., $12,159$.

Chouloutko, M. L. and Panfilova, G. A. (1960). Résection du poumon chez les malades souffrants de tuberculose primaire. Probl. Tuberk., 38, Nr. 1, p. 79 [in Russian. French summary, p. 85].

Danino, E. A., Evans, C. J. and Thomas, J. H. (1955). Tuberculous broncho-oesophageal fistula in a child. Thorax, 10,351.

Dufourt, A. (1956). Rapports de la phtisiogénèse pulmonaire tertiaire avec les perforations ganglionnaires intrabronchiques. tertiaire avec les perfora
Presse méd., 64, 1351 .

Eliasberg, H. and Neuland, W. (1920). Die epituberkulöse Infiltration der Lunge bei tuberkulösen Säuglingen und Kindern. Jb. Kinderheilk., 93, 88.

Frostad, S. (1959a). Lymph node perforation through the bronchial tree in children with primary tuberculosis. Acta tuberc. scand. Suppl. 47, p. 104.

(1959b). Segmental atelectasis in children with primary tuberculosis. Amer. Rev. Tuberc., 79, 597.
Gerbeaux, J., Baculard-Beauchef, A. and Hatémi, N. (1959). Prevention des séquelles bronchiques de la tuberculose ganglio-pulmonaire de première invasion par le traitment hormonal. Presse méd., 67, 1285 .

Gierhake, W. and Martens, E. (1960). Ergebnisse der Resektionsbehandlung der Lungentuberkulose bei Kindern und Jugendlichen. Beitr. Klin. Tuberk., 121, 641.

Ginn, B. H. and Cole, F. H.' (1958). Pulmonary resection for tuberculosis in children. Surg. Gynec. Obstet., 160, 196.

Giraud, P., Métras, H. and Grégoire, M. (1956). À propos des indications chirurgicales au cours de la tuberculose gangliopulmonaire de enfant. In Le traitement de la tuberculose de l'enfant, Séminaire, Paris, 1955, pp. 148-150. Centre International de l'Enfance. Travaux et Documents X. Masson, nation

,, Laval, P., Payan, H., Giraud, H. and Gregoire, M. (1958). Examen anatomique des pièces de résection réalisée au cours de la primo-infection. Pédiatrie, 13, 483.

Görgényi-Göttche, O. (1958). Tuberculosis of the Thoracic Lymph Nodes (Monograph). Medicina, Budapest.

Gotti, D. and Cetrullo, C. (1958). Sindrome ostruttiva tracheobronchiale da granuloma tubercolare in bambina della prima bronchiale da granuloma tubercolare in b
infanzia. Clin. pediat. (Bologna), 40,225 .

Haggenmüller, F. (1956). Zur Frage der Bronchialalteration durch tuberculöse intrathorakale Lymphknoten. Arch. Kinderheilk., 153,225

Hansen, J. L. (1959). Pulmonary resection for tuberculosis in children. Acta tuberc. scand., Suppl. 47, p. 143.

Hirdes, J. J. and Bronkhorst, C. L. (1956). Indicaciones y resultados del tratamiento por resección de la tuberculosis pulmonar en el niño. Rev. esp. Pediat., 12,87.

Huish, D. W. (1956). The surgical treatment of pulmonary tuberculosis in childhood and adolescence. Thorax, 11, 186.

Jamet, G. and Petithomme, H. (1958). Les tuberculoses initiales sévères de l'enfance et de l'adolescence; problèmes diagnostiques et thérapeutique actuels. Poumon, 14, 289.

Joppich, G. (1956). Der Bronchialeinbruch. Münch. med. Wschr. 98, 964.

(1958). Zur Klinik der perfprierenden endothorakalen Lymphknotentuberculose beim Kinde. Berl.Med.Jubiläumausg. p. 30 .

Kerényi, I. and Szöts, I. (1956). Indikationen und Ergebnisse der chirurgischen Behandlung der Lungentuberkulose im Kindesund Pubertätsalter. Tuberk. Arzt., 10, 449.

Laval, P. (1959). Le pronostic éloigné de la primo-infection tuberculeuse chez l'enfant (d'après 635 observations). Pédiatrie, 14, 559.

Parrot, J. (1876). Lésions des poumons et celles des ganglions trachéo bronchiques chez les enfants. C.R. Soc. Biol. (Paris), 28 (6 ser. 3$), 308$

Rzepecki, T. (1959). Pneumonectomy with resection of tracheobronchial lymph nodes in tuberculosis in children. Gruźlica, 27, 219.

Schwartz, Ph. (1957). Les altérations tuberculeuses lymph-adénobronchogènes. Réponse aux critiques. Presse méd., 65, 2213.

_- anc' Ståhle, I. (1958). Vergleichende pathologisch-anatomische und klinisch-radiologische Untersuchungen über Lungentuberkulose. I. Mitteilung: Fall von äquisektorialem Aspirations-filtrat bei parabronchialer Lymphknotenkaverne und vergrösserten tuberculösen Lymphknoten. Acta tuberc. scand., 35, 106.

Simon, K. (1958). Die Erfolge der chirurgischen Behandlung der Lungentuberkulose bei Kindern und Jugendlichen. Med. Mschr., 12, 618 .

Thomas, D. E. and Winn, D. (1960). Middle lobectomy for tuberculosis in childhood. J. Thor. cardiovasc. Surg., 39, 175.

Vossschulte, K. (1958). Chirurgische Therapie der Lymphknotentuberkulose des Mediastinums. Beitr. Klin. Tuberk., 117, 557. 